\title{
ANALISIS FAKTOR-FAKTOR YANG MEMPENGARUHI EFEKTIFITAS TERMINAL MAKASSAR METRO
}

\author{
Ashari Abdullah \\ Dosen Prodi Arsitektur, Fakultas Teknik Universitas Muhammadiyah Makassar, \\ ashari.abdullah@unismuh.ac.id
}

\begin{abstract}
ABSTRAK
Kebijakan relokasi Terminal Makassar Metro menyisakan persoalan serius yaitu fungsi terminal sebagai fasilitas transit bagi penumpang bus antar kota kurang efektif, hal ini dapat di lihat dari rendahnya tingkat pemanfaaan terminal oleh penumpang. Situasi ini berdampak pada munculnya terminal bayangan di kota Makassar. Penelitian ini bertujuan untuk mengetahui faktor-faktor yang mempengaruhi efektifitas Terminal Makassar Metro berdasarkan persepsi penmpang. Teknik analisis yang di gunakan adalah Principal Component Analysis. Hasil penelitian menunjukkan bahwa ada lima faktor yang mempengaruhi efektifitas terminal yaitu kondisi fasilitas, kualitas lingkungan, desain arsitektur, Informasi, da kemudahan transfer.
\end{abstract}

Kata Kunci : Efektifitas Terminal, Principal Component Analysis, Penumpang, Terminal Makassar Metro,

\section{PENDAHULUAN}

Kota makassar sebagai salah satu kota metropolitian di Indonesia memiliki Terminal Makassar Metro sebagai prasarana transportasi untuk keperluan menaikkan dan menurunkan penumpang dan atau barang serta untuk mengatur kedatangan dan pemberangkatan kendaraan umum, yang merupakan salah satu wujud simpul jaringan transportasi (UU No 22 Tahun 2009 Tentang Lalu Lintas dan Angkutan Jalan). Berdasarkan Peraturan Menteri No 132 tahun 2015 bahwa aktifitas transit penumpang bus antar kota harus dilakukan di dalam terminal. Terminal sebagai fasilitas transit merupakan bagian dari sistem transportasi yang bertujuan untuk mengintegrasikan dan mengefisiensikan perpindahan moda penumpang dari berbagai rute dan moda transportasi yang berbeda (Pitsiava-Latinopoulou \& lordanopoulos, 2012).

Dimitriou (1993) mengatakan ada empat alasan relokasi terminal yang dilakukan pemerintah indonesia yaitu untuk mengurai kemacetan di terminal lama, meningkatkan kapasitas terminal, meningkatkan PAD dan menjadi roda penggerak pertumbuhan daerah sekitar. Dari Empat tujuan tersebut hanya dua yang terealisasi di Terminal Makassar Metro yaitu dapat mengurai kemacetan di terminal lama dan meningkatkan kapasitas terminal, namun terkain PAD dan penggerak pertumbuhan kota kurang terealisasi. Pada awal beroperasinya Terminal Makasar metro sangat aktif hal ini dapat dilihat dari tingginya jumlah penumpang yang melakukan aktifitas transit di terminal namun seiring waktu jumlah penumpang yang melakukan transit di terminal semakin menurun.

Keberadaan Terminal Makassar Metro Makassar diperlukan dalam mendukung mobilitas penduduk baik yang akan berangkan dari dalam Kota Makassar maupun yang datang dari luar Kota Makasar dan menciptakan interkoneksi transpotrasi antara transportasi antar kota dengan transportasi di dalam kota. Disamping itu, Terminal Makassar Metro pun berfungsi sebagai sarana penunjang bagi peningkatan Pendapatan Asli Daerah Kota Makassar.

Terminal Makassar Metro terletak pada Kecamatan Biringkanaya dengan jarak \pm 500 $\mathrm{m}$ dari ruas jalan Perintis Kemerdekaan $\mathrm{km}$ 15. Terminal ini secara fungsional termasuk dalam terminal penumpang tipe $A$, hal ini bisa dilihat dengan adanya pelayanan angkutan bus antar provinsi atau yang biasa disebut bus Antar Kota Antar Dalam Provinsi (AKDP) dan Antar Kota Antar Provinsi (AKAP), selain melayani angkutan umum penumpang dalam kota.

Terminal Makassar metro merupakan Terminal bus antar kota tipe A yang berada di kota makassar terminal yang dibangun sejak tahun 2003 dan efektif beroperasi pada tahun 2004. Awalnya terminal ini berasal dari terminal panaikang yang berada di jalan urip sumoharjo di kilometer $5 . \quad$ Seiring pertumbuhan dan perkembangan kota, terminal panaikang menjadi kekurangan 
kapasitas sehingga menimbulkan kesemrautan di lingkungan sekitar, hal ini berdampak juga pada kemacetan di sekitar terminal, apalagi terminal berada di jalan poros utama kota Makassar.

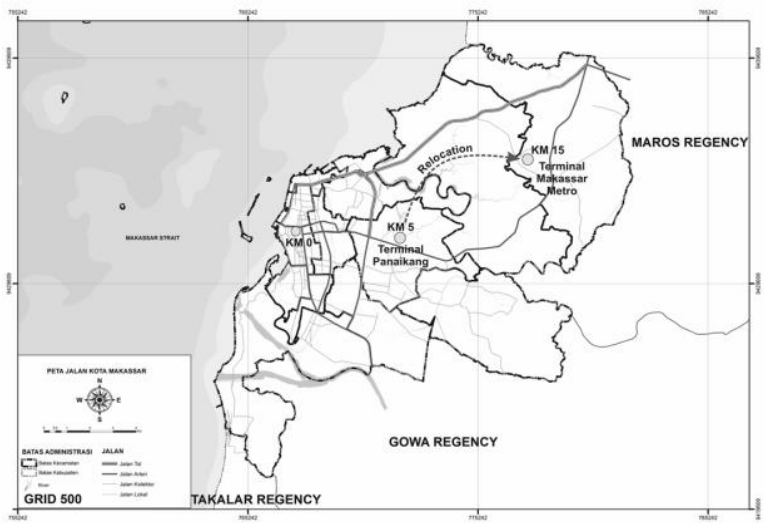

Gambar 1. Peta Relokasi Terminal Panaikang ke Terminal Makassar Metro

Permasalahan yang muncul yaitu aktifitas transit penumpang bus antar kota cenderung dilakukan di luar terminal atau di sebut terminal bayangan baik itu di pinggir jalan maupun di Pool bus yang terletak di dalam kota. Walaupun berbagai upaya dilakukan untuk menekan terminal bayangan namun kebijakan tersebut kurang efektif menkan keberadaan terminal bayangan

Oleh karena itu penelitian ini penting untuk dilakukan agar dapat di analisis mengenai faktor-faktor yang mempengaruhi penumpang dalam menggunakan terminal sebagai fasilitas transit, sehingga fasilitas terminal dapat lebih bermanfaat bagi penumpang bus antar kota.

\section{TINJAUAN PUSTAKA}

Penelitian tentang terminal bus antar kota masih sangat terbatas, Cuylits (1972) meneliti tentang kriteria lokasi terminal bus antar kota dengan pendekatan kualitatif. Wicaksono dkk (1997) meneliti tentang faktor yang mempengaruhi penurunan tingkat pemanfaatan terminal dengan pendekatan model logit, hasil penelitiannya menunjukkan bahwa waktu total yang di habiskan oleh penumpang berpengaruh terhadap pengguna terminal bus antar kota. Waktu total tersebut terdiri dari acces time, transfer time dan waiting time. Roca-Riu \& Estrada (2012) meneliti tentang model optimasi untuk menentukan lokasi terminal di dalam kota dengan meminimalkan total cost penumpang dan operator bus. Sedayu (2013) meneliti tentang pelayanan terminal bus antar kota merekomendasikan standar pelayanan minimal (SPM) terkait lokasi, letak dan aksesibiltas terminal untuk meningkatkan kepuasan pengguna, Abdullah, dkk (2018) meneliti tentang Model pengukuran kualitas pelayanan terminal makassar metro yang menggunakan analisis SEM, hasil penelitiannya menunjukan ada 5 faktor yang terbentuk yaitu aksesibilitas, kemudahan transfer, pelayanan terminal, dan keandalan pelayanan.

\section{Tabel 1. Atribut Penelitian}

\begin{tabular}{l}
\hline Atribut \\
Ketersediaan Informasi Perjalanan di terminal \\
Informasi ketersediaan tiket \\
Kemudahan membawa barang/bagasi \\
Koordinasi antara operator bus/panther dengan \\
pengelola \\
Kemudahan mencapai terminal (lokasi terminal) \\
Pelayanan angkutan umum ketermina / sebaliknya \\
Pelayanan Staf yang terampil dan sopan \\
Keamanan di dalam terminal saat malam hari \\
Pencahayaaan diterminal \\
Tata ruang area sekitar terminal \\
desain interior dan eksterior terminal \\
Kebersihan terminal \\
Suhu ruangan, terlindung dari hujan dan panas, \\
perputaran udara di terminal \\
Kondisi terminal yang tidak bising/ribut \\
kualitas udara di terminal \\
ketersediaan tempat duduk di terminal \\
fasilitas perbelanjaan di terminal, kafe, \& Restorant
\end{tabular}

Dalam penelitian di adaptasi penelitian dari Hernandez dan monzon 2017 yang meneliti menganti faktor utama yang menentukan efisiensi interchange di Spanyol. Dalam penelitiannya ada 37 indikator yang igunakan, namun dalam penellitian ini hanya 17 yang di gunakan dengan pertimbangan beberapa indikator memiliki subtansi yang mirip serta untuk menghindari kejenuhan dari responden yang harus mengisi banyak kuisioner.

\section{METODE}

Penelitian ini dilakukan di Terminal Makassar metro. Penelitian ini dilakukan selama 3 bulan dari bulan maret -mei 2018. Pengambilan sampel dilakuna dengan teknik 
accidental sampling. Jumlah responden yang di dapatkan sebanyak 70 responden.

Adapun teknik analisis yang digunakan yaitu Principal Component Analysis menggunakan program SPSS. Tahapan yang di lakukan dalam analisi ini yaitu :

\section{Tahap 1. Konsistensi data}

Untuk menyelesaikan analisis faktor, beberapa prosedur di butuhkan untuk memastikan bahwa matriks data memiliki yang cukup untuk penerapan analisis faktor.. Prosedur tersebut meliputi uji matrik korelasi, memeriksa matriks korelasi anti-image menilai kecukupan sampel Kaiser-Meyer-Olkin (KMO) dan uji Bartlett's.

Uji matriks korelasi adalah metode yang di gunakan untuk menentukan kesesuaian analisis faktor. Hair dkk (2010) merekomendasikan nilai korelasi lebih besar dari 0.3 dalam matriks yang menunjukkan bahwa indikator tesebut memiliki faktor bersama. Oleh karena itu hasil tersebut dapat dimasukkan ke dalam analisis faktor Jika tidak maka matriks data tidak sesuai untuk analisis faktor (Pallant, 2007; Chinna, 2009).

Anti-image correlation matrix adalah nilai negatif dari korelasi parsial (Hair dkk, 2010). Anti-image correlation matrix merupakan matriks yang menunjukkan angka negative dari korelasi parsial yang terdapat antar variabel (Tabachnick \& Fidell, 2007). Namun jka nilai anti-image correlation (semakin negatif) antar variabel semakin besar, maka penggunaan analisis faktor harus kembali dipertimbangkan (Stewart, 1981).

Kaiser Meyer Olkin Measure of Sampling (KMO) adalah indeks perbandingan jarak antara koefisien korelasi dengan koefisien korelasi parsialnya. Jika jumlah kuadrat koefisen korelasi parsial di antara seluruh pasangan variabel bernilai kecil jika dibandingkan dengan jumlah kuadrat koefisien korelasi, maka akan menghasilkan nilai KMO mendekati 1. Adapun nilai klasifikasi KMO sebagai berikut, 0,9 (Marvelous), 0,8 (Meritorius), 0,7 (midding), 0,6 (mediocre), 0,5 (miserable), <0,5 (unacceptable). Nilai KMO dianggap mencukupi jika lebih dari 0,5 (Kaiser \& Rice, 1974).

Bartlett's Test of Sphericity merupakan salah satu metode yang digunakan untuk melihat korelasi antar variabel secara keseluruhan atau sekaligus. Bartlett's Test of Sphericity menguji hipotesis bahwa matriks korelasi adalah matriks identitas. Jika hipotesis ini diterima, maka penggunaan analisis faktor perlu dipertimbangkan (Hair $\mathrm{dkk}, 2010$ )

\section{Tahap 2. Metode ekstraksi faktor}

Terdapat tiga kriteria umum yang digunakan untuk menentukan jumlah faktor (Hair dkk 2010 ; Janssens dkk., 2008; Pallant, 2007; Stewart, 1981).

Kriteria pertama yaitu Nilai eigen menggambarkan jumlah variansi yang dapat dijelaskan oleh sebuah faktor. Nilai-nilai dari sebuah variabel setelah distandardisasikan akan memiliki variansi sebesar 1 . Hal ini berimplikasi bahwa jika sebuah faktor memiliki nilai eigen $<1$, artinya faktor tersebut membawa informasi yang lebih sedikit dibandingkan variabel awal. Atau dengan kata lain, kemampuan menjelaskan varians data (yang diukur dengan variansi) oleh faktor tersebut lebih buruk dibandingkan dengan kemampuan variabel awal. Jika faktor ini dimasukkan dalam analisis lebih lanjut, maka akan bertentangan dengan tujuan penggunaan analisis faktor. Kesimpulannya, akan sangat beralasan jika faktor yang diekstraksi dibatasi pada faktor-faktor dengan nilai eigen $>1$.

Kriteria kedua yaitu kriteria scree plot, sebuah scree plot adalah plot dari nilai eigen terhadap jumlah faktor, dalam urutan proses ekstraksi. Bentuk dari plot dapat digunakan untuk menentukan jumlah faktor yaitu dengan memperhatikan kecuraman garis yang ada. Proses ekstraksi berhenti pada titik di mana garis menjadi relatif lebih landai. Proses ekstraksi berhenti pada titik yang merupakan pangkal garis yang mengalami penurunan yang paling tajam.

Krieria ketiga yaitu Kriteria variansi yang terjelaskan. Pada kriteria ini faktorfaktor akan diekstraksi sampai dengan jumlah proporsi nilai eigen kumulatifnya melebihi suatu batas yang dianggap cukup memuaskan. (Hair dkk., 2010 merekomendasikan dalam ilmu sosial nilai $60 \%$ atau kurang (dalam keadaan tertentu) dari total varian. 


\section{Tahap 3. Metode Rotasi}

Ada dua jenis rotasi yang di gunakan dalam perhitungan EFA yaitu Oblique dan Orthogonal. VARIMAX, QUARTIMAX dan EQUIMAX adalah tiga rotasi ortogonal, namun VARIMAX merupakan metode rotasi faktor yang paling populer dan sering di terapkan. Principal component analysis (PCA) dan rotasi VARIMAX secara khusus digunakan dalam penelitian ini untuk mengetahui faktorfaktor dari 17 atribut. Rotasi VARIMAX digunakan untuk menyederhanakan kolom dalam matrix faktor (Hair dkk., 2010).

\section{HASIL DAN PEMBAHASAN Karakteristik Responden}

Dar hasil analisis karakteristi responden dapat dilihat pada gambar 2. Dari gambar dapat dilihat bahwa sebagian besar responden berumur 18-25 tahun diikuti responden berumur 26-40 tahun sisanya responden yang berumur diatas 40 tahun. Dari jenis kelamin sebanayk $61,43 \%$ besar responden adalah perempun dan sebanyak $38,57 \%$ repondena adalah pria ,sedangakn dari segi pekerjan sebanyak $40 \%$ responden berstau pelajar/mahasiswa, 30\% memilik pekerjaan PNS, 8,75\% memiliki pekerjaan wiraswasta. Dari segi pendidikan sebanyak $67,14 \%$ responden adalah lulusaN SD-SMA, dan sebanyak $32,86 \%$ merupakan lulusan perguruan tinggi.

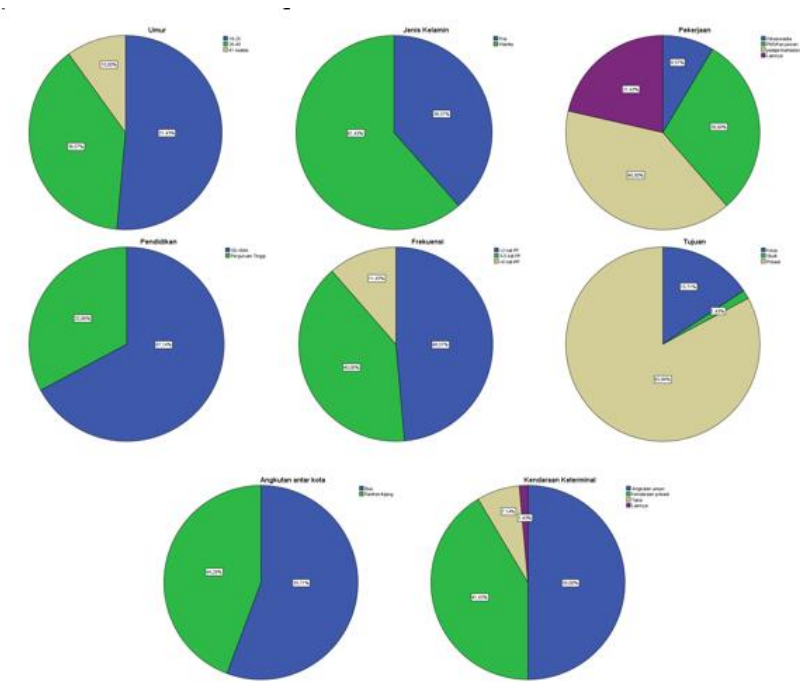

Gambar 2. Karakteristik Responden

Dari segi frekuensi perjalanan sebanyak 48,57\% responden melakukan pejalana keluar kota $<2$ kali Pulang pergi $40 \%$ melakukan perjalann 3-5 kali pulang pergi, dan hanya $11,43 \%$ penumpang yang melakna peralanan lebih dari 6 kali pulang pergi. Dari segi tujuan perjalanan, sebanyak $82,86 \%$ reponden melakukan perjalanan untuk tujuan pribadi, $15,71 \%$ melakukan perjalanan dengan tujuan pekerjaan dan hanya $1,43 \%$ yang melakukan perjalanan untuk keperluan studi.

Dari segi jenis kendaraan keterminal sebanyak $50 \%$ responden menggunakan angkutan umum ke terminal, sebanyak $41,43 \%$ menggunakan kendaraan pribadi, hanya $7,14 \%$ yang mengunkan taksi. Dari segi jenis angkutan antar kota yang digunakan responden sebanyak 55,71\% mengunakan bus dan 44,29\% menggunaka panther.

Jadi berdasarkan hasil analisis karektisitik responden di dapatkan bahwa sebagian besar responden merupakan pelajar/mahasiswa yang melakukan perjalanan dengan tujuan pribadi atau pulang kampus dengan frekuensi perjalaanan <2 kali PP.

\section{Analisis Faktor}

Berdasarkan tabel 2 hasil uji KMO 0,786 memenuhi syarat (Kaiser, 1974), dan uji bartlett menunjukkan bahwa hasil signifikan pada nilai 0,001\% (Hair dkk., 2010).

Tabel 2. Uji KMO and Bartlett's

\begin{tabular}{ccc}
\hline \multicolumn{3}{c}{ KMO and Bartlett's Test } \\
\hline \multicolumn{3}{c}{$\begin{array}{c}\text { Kaiser-Meyer-Olkin Measure of } \\
\text { Sampling Adequacy. }\end{array}$} \\
\hline $\begin{array}{c}\text { Bartlett's Test } \\
\text { of Sphericity }\end{array}$ & Approx. Chi-Square & 752,666 \\
\cline { 2 - 3 } & $\mathrm{df}$ & 136 \\
\cline { 2 - 3 } & Sig. &, 000 \\
\hline
\end{tabular}

Dari hasil ekstraksi faktor pada tabel 3 didapatkan lima faktor dengan nilai cumulative variance explain $74,028 \%$, nilai ini lebih besar dari nilai yang di rekomendasikan sehingga dapat digunakan untuk analisis lanjut (Hair dkk., 2010; Hair, 2010). Pada gambar 3 dapat juga dilihat Kriteria scree plot yang menunjukkan grafik yang landai setelah di faktor kelima. 


\begin{tabular}{|c|c|c|c|c|c|c|c|c|c|}
\hline \multirow{3}{*}{ 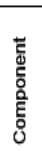 } & \multirow{2}{*}{\multicolumn{3}{|c|}{ Initial Eigenvalues }} & \multirow{2}{*}{\multicolumn{3}{|c|}{$\begin{array}{l}\text { Total Variance Explained } \\
\text { Extraction Sums of Squared } \\
\text { Loadings }\end{array}$}} & \multirow{2}{*}{\multicolumn{3}{|c|}{$\begin{array}{l}\text { Rotation Sums of Squared } \\
\text { Loadings }\end{array}$}} \\
\hline & & & & & & & & & \\
\hline & Total & $\begin{array}{c}\% \text { of } \\
\text { Variance }\end{array}$ & Cum. \% & Total & $\begin{array}{c}\% \text { of } \\
\text { Variance }\end{array}$ & Cum. \% & Total & $\begin{array}{c}\% \text { of } \\
\text { Variance }\end{array}$ & Cum. \% \\
\hline 1 & 6,556 & 38,564 & 38,564 & 6,556 & 38,564 & 38,564 & 2,721 & 16,008 & 16,008 \\
\hline 2 & 2,192 & 12,895 & 51,460 & 2,192 & 12,895 & 51,460 & 2,626 & 15,448 & 31,456 \\
\hline 3 & 1,545 & 9,085 & 60,545 & 1,545 & 9,085 & 60,545 & 2,573 & 15,133 & 46,589 \\
\hline 4 & 1,279 & 7,524 & 68,070 & 1,279 & 7,524 & 68,070 & 2,380 & 13,999 & 60,589 \\
\hline 5 & 1,044 & 6,139 & 74,208 & 1,044 & 6,139 & 74,208 & 2,315 & 13,620 & 74,208 \\
\hline 6 & 918 & 5,401 & 79,609 & & & & & & \\
\hline 7 & 686 & 4,037 & 83,645 & & & & & & \\
\hline 8 & 612 & 3,603 & 87,248 & & & & & & \\
\hline 9 & 551 & 3,240 & 90,488 & & & & & & \\
\hline 10 & 341 & 2,006 & 92,494 & & & & & & \\
\hline 11 & 304 & 1,789 & 94,283 & & & & & & \\
\hline 12 & 255 & 1,499 & 95,783 & & & & & & \\
\hline 13 & 200 & 1,179 & 96,962 & & & & & & \\
\hline 14 & 189 & 1,110 & 98,072 & & & & & & \\
\hline 15 & 158 &, 929 & 99,001 & & & & & & \\
\hline 16 & 121 & ,711 & 99,712 & & & & & & \\
\hline 17 &, 049 & ,288 & 100,000 & & & & & & \\
\hline \multicolumn{10}{|c|}{ Extraction Method: Principal Component Analysis. } \\
\hline
\end{tabular}

Tabel 3. Ekstraksi Faktor

\section{Tabel 4. Mtarix Rotasi}

Tabel 4. Mtarix Rotasi

\begin{tabular}{|c|c|c|c|c|c|}
\hline \multirow[b]{2}{*}{ Atribut } & \multicolumn{5}{|c|}{ Component } \\
\hline & 1 & 2 & 3 & 4 & 5 \\
\hline fasilitas perbelanjaan di terminal, kafe, \& Restorant & 0,78 & & & & \\
\hline ketersediaan tempat duduk di terminal & 0,74 & & & & \\
\hline Pencahayaaan diterminal & 0,63 & & & & \\
\hline Kebersihan terminal & 0,55 & & & & \\
\hline Keamanan di dalam terminal saat malam hari & 0,49 & & & & \\
\hline Kondisi terminal yang tidak bising/ribut & & 0,85 & & & \\
\hline $\begin{array}{l}\text { kualitas udara di terminal } \\
\text { Suhu ruangan, terlindung dari hujan dan panas, perputaran }\end{array}$ & & 0,83 & & & \\
\hline udara di terminal & & 0,59 & & & \\
\hline Tata ruang area sekitar terminal & & & 0,91 & & \\
\hline desain interior dan eksterior terminal & & & 0,90 & & \\
\hline Informasi ketersediaan tiket & & & & 0,85 & \\
\hline Ketersediaan Informasi Perjalanan di terminal & & & & 0,84 & \\
\hline Pelayanan Staf yang terampil dan sopan & & & & 0,66 & \\
\hline Pelayanan angkutan umum ketermina / sebaliknya & & & & & 0,76 \\
\hline Koordinasi antara operator bus/panther dengan pengelola & & & & & 0,74 \\
\hline Kemudahan mencapai terminal (lokasi terminal & & & & & 0,67 \\
\hline Kemudahan membawa barang/bagasi & & & & & 0,55 \\
\hline
\end{tabular}

Dari hasil rotasi pada tabel 4 didapatkan atribut dari faktor pertama yaitu fasilitas perbelanjaan di terminal, kafe, \& Restorant, ketersediaan tempat duduk di terminal, Pencahayaaan diterminal, Kebersihan terminal, Keamanan di dalam terminal saat malam hari disebut kondisi fasilitas. Atribut dari faktor kedua yaitu Kondisi terminal yang tidak bising/ribut, kualitas udara di terminal, Suhu ruangan, terlindung dari hujan dan panas, perputaran udara di terminal disebut kualitas lingkungan. Aribut dari faktor ketiga yaitu Tata ruang area sekitar terminal, desain interior dan eksterior terminal disebut desain arsitektur. Atribut dari faktor keempat yaitu Informasi ketersediaan tiket, Ketersediaan Informasi Perjalanan di terminal, Pelayanan Staf yang terampil dan sopan disebut informasi. Atribut dari faktor kelima yaitu Pelayanan angkutan umum keterminal / sebaliknya, Koordinasi antara operator bus/panther dengan pengelola, Kemudahan mencapai terminal (lokasi terminal), Kemudahan membawa barang/bagasi disebut kemudahan beralih moda.

Kondisi fasilitas terminal makassar metro saat ini cukup rendah pemeliharaannya, dalam atribut kondisi fasilitas kebersihan masuk sebagai kondisi fasilitas sedangkan di penelitian Hernandez and Monzon (2016) masuk dalam faktor kualitas lingkungan.

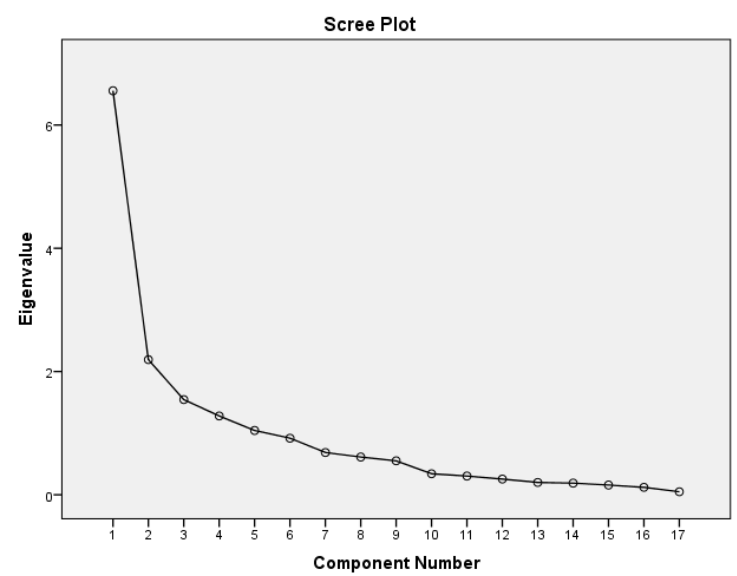

Gambar 3. Screen Plot

Kualitas lingkungan di terminal makassar metro kurang baik dari persepsi penumpang, hal ini karena kebisingan saat yag terjadi saat penumpang menunggu keberangkatan, kualitas udara yang kurang baik karena ruang tunggu terminal yang terbuka sehingga udara dari luar dapat berhembus keruang tunggu, hal ini juga berpengaruh terhadap suhu ruangan di ruang tunggu.

Dari segi desain arsitektur, terminal mengadaptasi bentuk dari bangunan tradisional bugis makassar, dan dari segi penataan terdapat ruang operator yang berada di dalam bangunan sehingga penumpang untuk mengakses ruangan 
tersebut harus melalui ruang tunggu, sehingga penumpang yang hendak mencari tiket mesti melakukan pergerakan yang lebih tinggi.

Dari segi informasi, penyediaan informasi masih kurang akurat dan kurang jelas, hal karena tempat informasi (layar TV) yang berukuran kecil dan kurang menjadi perhatian bagi penumpang untuk mendapatkan informasi yang akurat. Penumpang cenderung mencari informasi langsung kepada staf operator yang berada di dalam terminal untuk mendapatkan informasi perjalanan.

Dari segi kemudahan transfer, terminal saat ini hanya dilayani transportasi publik dalam kota berupa pete-pete, itupun hanya berlangsung hingga pukul 18.00 , setelah jam tersebut pelayanan pete-pete menurun drastis hal ini yang mengakibatkan penumpang menggunakan angkutan umum lain seperti taksi regular, taksi online, ojek.

Dari lima faktor tersebut dapat dikategorikan menjadi dua yaitu aspek fisik dan non fisik. Aspek fisik yaitu kondisi fasilitas, kualitas lingkungan dan desain arsitektur sedangkan aspek non fisik yaitu informasi dan kemudahan transfer.

\section{Implikasi manejerial}

Ada tiga rekomendasi manajerial dalam rangka meningkatkan efektifitas Terminal Makassar Metro yaitu pertama Meningkatkan Kualitas fisik bangunan, peningkatan kualitas fisik banguanan dapat dilakukan dengan cara penyediaan ruang tunggu yang lebih mengakomodasi keinginan penumpang sehingga penumpang dapat menunggu dengan nyaman karena tersedianya tempat duduk, pencahayan yang cukup baik disiang hari maupun di malam hari serta ruangan yang lebih bersih, dan tersedia fasilitas komersil di dalam terminal baik itu perbelanjaan, cafe maupun tempat makan. redesain terminal juga dapat dilakukan terhadap wajah terminal agar memiliki citra baru sebagai fasilitas transit penumpang bus antar kota

Rekomendasi kedua yaitu meningkatkan dan menjamin pelayanan yang berkualitas di dalam terminal, peningkatan pelayanan dapat dilakukan dengan cara menjamin ketersediaan, kejelasan dan ketepatan informasi perjalanan yang di butuhkan oleh penumpang baik itu informasi mengenai tiket dan jadwal operasiona angkutan antar kota. Pelayanan staf yang terampil dan sopan juga dapat meningkatkan efektifitas pelayanan terminal.

Rekomendasi ketiga yaitu Meningkatkan aksesibilitas terminal, peningkatan aksibilitas terminal dapat dilakukan dengan cara meningkatkan pelayanan transportasi publik dalam kota di terminal, serta kemudahan penumpang dalam melakukan transfer atau alih moda dengan cara menyediakan fasilitas pengangkat barang, serta koordinasi yang lebih baik antara operator dan pengelola sehingga informai yang sampai ke penumpang lebih akurat.

\section{KESIMPULAN}

Kecenderungan Penumpang melakukan aktifitas transit di terminal di pengaruhi aspek fisik dan non fisik. Dari aspek fisik faktor yang berpengaruh yaitu kondisi fasilitas, kualitas lingkungan dan desain arsitektur sedangkan aspek non fisik yaitu informasi dan kemudahan transfer. Oleh karena itu sebagai rekomendasi dalam rangka meningkatkan efektifitias terminal maka perlu memperhatikan ke lima faktor tersebut.

\section{DAFTAR PUSTAKA}

Abdullah, A., Yudono, A., Adisasmita, S. A., \& Akil, A. (2018). Measurement modelling of the perceived service quality of intercity bus terminal. In MATEC Web of Conferences (Vol. 181, p. 10003). EDP Sciences.

Chinna K, 2009. Structural equation modeling using AMOS. Kuala Lumpur: Malaysia.

Cuylits ER, 1972. Inter-city bus terminal location criteria: University of British Columbia.

Dimitriou, H.T. (1993), A Developmental Approach to Urban Transport Planning: An Indonesian Illustration, Oxford University Press, Kualalurnpur, Malaysia. 
Janssens W, De Pelsmacker P, Wijnen K, Van Kenhove P, 2008. Marketing research with SPSS. Pearson Education.

Hair J, . Black. WC, Babin., BJ, Anderson RE,(2010) Multivariate data analysis, a global perspective. New Jersey. Pearson. Ed 7, 816.

Hernandez, S. \& Monzon, A., (2016). Key factors for defining an efficient urban transport interchange: Users' perceptions. Cities, 50, pp.158-167.

Kaiser HF, Rice J, 1974. Little jiffy, mark IV. Educational and psychological measurement 34, 111-7.PitsiavaLatinopoulou, M. \& Iordanopoulos, P., (2012). Intermodal Passengers Terminals: Design Standards for Better Level of Service. Procedia - Social and Behavioral Sciences, 48, pp.3297-3306

Pallant J, 2007. SPSS survival manual: A step-by-step guide to data analysis with SPSS. New York, NY: McGrath Hill. Google Scholar.

Peraturan Menteri No 132 Tahun 2015 Tentang Penyelenggaraan Terminal penumpang angkutan jalan

Roca-Riu M, Estrada M, 2012. An evaluation of urban consolidation centers through logistics systems analysis in circumstances where companies have equal market shares. Procedia-Social and Behavioral Sciences 39, 796-806.

Sedayu A, 2013. Pemodelan Pelayanan Terminal Penumpang Transportasi Jalan Berbasis Kepuasan Pengguna. Program Doktor Teknik Sipil Program Magister dan Doktor Fakultas Teknik Universitas Brawijaya Malang.

Tabachnick BG, Fidell LS, 2007. Using multivariate statistics. Allyn \& Bacon/Pearson Education.

Stewart DW, 1981. The application and misapplication of factor analysis in marketing research. Journal of marketing research, 51-62.

Undang-undang No 22 Tahun 2009 Tentang Lalu Lintas Dan Jalan

Wicaksono A, Ohta K, Muromachi Y, Harata N, 1997. Study on the Impact of Intercity Bus Terminall Relocation to Utilization Level of Bus Terminal A Case Study of Probolinggo City, Indonesia. 